http://journals.ums.ac.id/index.php/ijolae

\title{
Challenges, Strategies, and Solutions of Teaching Bahasa Indonesia in Covid-19 Crises: Case in Khon Kaen University
}

\author{
Haiyudi ${ }^{1}$, Sitthipon Art-In ${ }^{2}$ \\ ${ }^{1-2}$ Faculty of Education, Khon Kaen University, Thailand
}

DOI: 10.23917/ijolae.v3i2.12369

Received: October $1^{\text {st }}, 2020$. Revised: December $2^{\text {nd }}, 2020$. Accepted: December $21^{\text {st }}, 2020$.

Available Online: January $11^{\text {st }}, 2021$. Published Regularly: May $1^{\text {st }}, 2021$.

\begin{abstract}
The purpose of this study is to identify the challenges experienced in teaching and learning Bahasa Indonesia for foreigners during covid-19 as well as to find out the strategies and solutions undertaken during online learning. The method in this research is descriptive qualitative using case study approach in Bahasa Indonesia course at Khon Kaen University. The subjects in this study were 3 teachers and 2 students of Bahasa Indonesia class. The finding shows some challenges of learning Bahasa Indonesia such as barriers in communication, the low ability of self-regulated learning owned by students, and the lack of control over the morals and behavior of students during distance learning. While, the solutions offered are still technologybased learning, making short videos as learning material to improve emotional relationships between students and teachers, reducing the level of difficulty and prioritize meaningful learning, and conducting multi-literacy learning. On the other hand, the techniques used are producing teachers' labs, conduct selfassessment as a reflection of self-regulated learning, and involving parents as substitutes for instructors in controlling values and morals. Self-regulated learning, as well as parental involvement, are extremely needed.
\end{abstract}

Keywords: teaching challenges, teaching strategies, covid-19 pandemic

Corresponding Author:

Haiyudi, Faculty of Education, Khon Kaen University, Thailand

Email: haiyudi@gmail.com

\section{Introduction}

Coronavirus Disease 2019 (Covid-19) globally started out breaking since the end of 2019. Almost all countries experienced the Covid-19 outbreak, including Thailand. Speculation about the origins of the Covid19 case that emerged has been well known globally. One of them was reported that this virus is originated from Wuhan, China (WHO, 2020). Various policies emerged to stop the spread of this virus. Each country chooses and implements a different strategy. Full quarantine, partial lockdown, social distancing, and physical distancing are the popular steps taken by many countries. With the implementation of the policy, almost all aspects experienced a crisis. The education aspect is one of the sectors that is affected by these policies. Basic and higher education in all countries even experiences severe disruption because it is affected by the policies adopted by the Thai government to prevent the country from the covid-19 outbreak.

Due to the widespread of Covid-19, Thailand decided to implement some policies known as lockdown, social distancing, physical distancing, and taking emergency decree until August 31st (Bangkok Post, 2020). It is a form of adherence to WHO's 
recommendations. Greenstone \& Nigam (2020) said that social distancing can distance and even save people in quite a large amount, which is about one million people. In line with this policy, the Thai government closed various crowded places where are expected to be placed for the spread of the virus. Shopping places, sports venues including educational institutions were closed. Khon Kaen University is one of many educational institutions closed to stop the spread of the virus. This happened similarly in many educational institutions outside of Thailand which were closed due to the spread of covid-19. All learning that was previously done conventionally, however, must be transformed into virtual. Learning from home was the policy taken since March 2020 .

Long distance learning or online learning was adopted by the Thai government with various consequences. Weaknesses and strengths of online learning are specifically very complex. The need for an internet quota is one of the various problems recognized by many parties. Besides the lack of motivation to learn due to the absence of two-way communication becomes one of the problems caused by online learning. However, online learning also has various advantages. One of them is space and time flexibility. Students can do the learning process anytime and anywhere. Besides, they can repeat the learning obtained whenever and wherever they are (Hidayat, Dasrun \& Noeraida, 2020). This happened in all educational institutions around many countries including Thailand. This policy is a crisis management effort that occurs in many sectors. As Smith (2005) explains that crisis management is a treatment that must be done because of the issues that occur out of control. Current conditions are conditions beyond control (WHO, 2020), so critical management must be taken, one of which is by conducting online learning.

In teaching and learning Bahasa Indonesia, which is also a foreign language for Thai students, it is quite possible that online learning will become an additional problem. Language and semantic barriers in learning have been becoming problems since online learning has not been implemented. Silva (1993) gives several ideas in Brown (2007) related to minimizing problems that arise during foreign language learning. First, the teacher must use an approach that is very attractive to students. Both teachers must understand the socio-culture and language between native language speakers and foreign languages (which are learned). This is intended to facilitate the language of instruction in the classroom. Third, the level of complexity of the assessment will differ between the teaching of native speakers and foreign languages. The indicators used should not be the same. This is because of the limitations possessed by students regarding foreign languages they learned. If so, the approach used in teaching foreign languages during this pandemic must be well thought out. Furthermore, sociocultural and linguistic understanding should be easily carried out through two-way communication (Lenunberg, 2010). However online learning makes it running slow.

The purpose of this study is to identify the problems that arise because of the online learning undergone by the Thai government. Moreover, this research is also to find out the strategies and solutions offered in teaching and learning Bahasa Indonesia at Khon Kaen University. However, learning foreign language processes will be precisely different from learning a language that belongs to ones' mother tongue (Brown, 2007). It will bring another sub-problem to appear.

Besides, learning innovation under the instruction of a University must have its weaknesses and strengths. But, it should 
meet the proposed students' improvement as the goal of meaningful learning is a process to change students' attitudes towards better (Cohen, Hersh, 1972). Similarly, Hanafi, Adu, and Muzakkir (2018) define learning as one of the processes of managing a particular environment to change behavior towards better and responding well to certain situations. In learning Bahasa Indonesia, which is a foreign language, this online learning will be an extra challenge for teachers. Therefore, it seems very necessary to know and identify problems that arise in learning Indonesian during online learning as well as the solution and strategies to support the learning process.

On the other hand, a learning strategy is very important to learn and set. As it is so, the teacher is an important element in determining learning strategies. O'Malley \& Chamot (1990) says that learning strategies are certain thoughts used to understand and access new knowledge. In the context of learning in schools, learning strategies are the efforts of teachers based on creative ideas that aim to help the learning process of students. Therefore, it is emerged to identify how teaching and learning of Bahasa Indonesia at Khon Kaen University during this Covid-19 pandemic. While it's also prominent to know how universities in Thailand respond to the online learning process so that it can be used as a comparison in teaching Bahasa Indonesia in Khon Kaen University to others. Therefore, this study is hoped to be a model of the teaching and learning of Bahasa Indonesia during Covid-19 Pandemic.

\section{Method}

This research belongs to a qualitative descriptive study. More specifically, this study uses a case study approach that aims to examine the question of why and how a phenomenon occurs (Prihatsanti, Suryanto,
Hendriani, 2018). This research was conducted at Khon Kaen University, under the ASEAN Language Center located at the Faculty of Humanity and Social Science. The participants of this study were 3 teachers and 2 students of Bahasa Indonesia under Bahasa Indonesia class in Khon Kaen University where the case study take place. Furthermore, this research was conducted in July 2020.

The data collecting method was semistructured interviews conducted with teachers of Bahasa Indonesia as well as two students who are currently studying Bahasa Indonesia. Therefore, the data collecting instruments were the interview questions addressed to the respondents related to the challenges, strategies, and solutions of teaching Bahasa Indonesia. Hence, to the validity of the study, researchers conducted a crosscheck on the data provided by conducting interviews with 2 students of Bahasa Indonesia which is familiarly known as the triangulation process. Thus, data analysis was carried out through several stages. The first stage is data collection from the respondents by interviewing, data reduction based on the script of the obtained data after the interviewing process. After that, the data presented in which a table is used to present. Right after, data conclusion is the last step of this study which will be presented by the same report of data presentation (Miles \& Huberman, 2009).

\section{Result and Discussion}

a. Result

The interview result of this study refers to qualitative data. Thus the data will be presented into a descriptive table to be easily read. The table 1 is describing the study group of this research and the response toward topics can be furtherly seen through table 2 . 
Table 1 The Detail of Participants of the Study

\begin{tabular}{cc}
\hline Participants & Nationality \\
\hline Teacher 1 & Indonesia \\
Teacher 2 & Indonesia \\
Teacher 3 & Indonesia \\
Student 1 & Thailand \\
Student 2 & Thailand \\
\hline
\end{tabular}

Table 2 Descriptive Table of the Challenges, Strategies, and Solutions

\begin{tabular}{|c|c|c|}
\hline Challenges & Strategies & Solutions \\
\hline $\begin{array}{l}\text { a. The face to face class cannot } \\
\text { be established. } \\
\text { b. Teaching a foreign language } \\
\text { using another foreign lan- } \\
\text { guage } \\
\text { c. Reducing the intensiveness of } \\
\text { training. } \\
\text { d. The low level of Self- } \\
\text { Regulated Learning (SRL) in } \\
\text { terms of Bahasa Indonesia. } \\
\text { e. There is no control over the } \\
\text { attitude and moral. }\end{array}$ & $\begin{array}{l}\text { a. Ensuring students can ac- } \\
\text { cess all the required techno- } \\
\text { logy and devices. } \\
\text { b. Strengthening parental } \\
\text { involvement to maintain } \\
\text { students' attitudes. } \\
\text { c. Using teachers' lab to pro- } \\
\text { duce the pre-recording vi- } \\
\text { deo of teaching } \\
\text { d. Self-Assessment done by } \\
\text { students. }\end{array}$ & $\begin{array}{l}\text { a. Maximizing the use of techno- } \\
\text { logy to support the teaching and } \\
\text { learning } \\
\text { b. Using short video recording to } \\
\text { gain students response to lear- } \\
\text { ning } \\
\text { c. Simplifying the level of difficul- } \\
\text { ties. } \\
\text { d. Conducting multi-literacy lear- } \\
\text { ning as an effort to do self- } \\
\text { regulated learning. }\end{array}$ \\
\hline
\end{tabular}

From the presented table above, the challenges experienced in learning Bahasa Indonesia during this remote or online learning are not in the form of technological challenges. In general, the challenges obtained are the challenges of learning systems that are the nature of communication in a foreign language.

Additionally, the strategies and solutions undertaken are related to the equality of technology and devises access, parental assessment, employing pre-recording, and students' self-assessment. Previously, negotiations were expected to reach an agreement on using a technology-based learning platform. This is because of the emergence of many platforms that can be used so that it confuses if it does not focus on a particular platform. Besides, the negotiation also aims to ensure that all students can access the same technology to support distance learning. Self-regulated learning is also an attempt to overcome the weakness of parental involvement. However, parental involvement in the child's learning process is a must.

On the other sides, the solution offered in the teaching and learning of Bahasa Indonesia is about maximizing the use of technology to support the teaching and learning, using short video recording to gain students response to learning, simplifying the level of difficulties, and also conducting multi-literacy learning as an effort to do selfregulated learning. Those kinds of solutions are offered to the teaching and learning process of Bahasa Indonesia at Khon Kaen University.

\section{b. Discussion \\ 1) Challenges Experienced during Online Learning of Bahasa Indonesia \\ The problems arising from Covid-19 seem to be a great challenge. Education is one of many sectors affected by this}


pandemic, while, Thailand is just one of many countries that decided to take immediate action. The policy undertaken by the Thai government to close schools has been started on 18 March 2020 (Kompas, 2020). By the closure of schools and universities, Thailand automatically commanded online learning in the teaching and learning process.

This pandemic demands every school and institution have a course based on technological preparation. In Thailand, Information and Communication Technology (ICT) has been categorized very well as the Thai government had implemented One Tablet Per Child (OTPC) or one tablet child (Yunardi, 2014). Therefore, to university students, ICT is not categorized as a fundamental problem anymore. Problems that arise precisely are the existence of new challenges to teaching methods and strategies in addressing this situation. This is because of the difference between Thai and Bahasa Indonesia which are specifically recognized as semantics and socio-language barriers in education.

Based on interviews conducted with three teachers, Andi Retno then initialed as Teacher 1, Uyun Nurun then initialed as Teacher 2, and Abil D then initialed as Teacher 3, several problems can be concluded. However, overall the perceived problem is a problem in the effectiveness of communication in learning (Fatma, F., Prayitno, H. J., Jamaludin, N., Jha, G. K., \& Badri, T. I.; 2019). However, communication barriers in the form of semantics barriers which belong to language barriers (Lenunberg, 2010). As foreign language learning, the problem of semantic barriers is something to think about, because the process of delivering and receiving ideas will take longer than expected (Brown, 2007). This is reinforced by the difference in communicating language in which English is often used. For more details, here are the responses of some teachers of Bahasa Indonesia regarding the challenges of the teaching and learning process of Bahasa Indonesia.

First, the teaching system during this pandemic poses a challenge that is not establishing face-to-face action as in the classroom. According to Teacher 2, teaching foreign languages by using other foreign languages is much more ineffective, thus it will be getting worst when it is done remotely. The need to establish an emotional relationship between teachers and students is much more needed so that learning becomes easier. Similar to other languages, Bahasa Indonesia also has four skills namely listening, speaking, reading, and writing. These skills will be very difficult to practice when conducting remotely. Then, some challenges due to communication barriers cannot be denied anymore. Communication barriers that often occur are delays in processing the instructions intended by the teacher. Besides, the problem that comes from the teacher is the lack of ability to speak Thai, so the instructions delivered are less than optimal for students to understand.

Second, as language is learning that must be trained, online learning in Bahasa Indonesia will reduce the intensiveness of practice especially for those students who are still at the basic level. Language skills that must still be guided are very difficult to through online. As Teacher 1 said that every semester, students will be offered a target about drilling new vocabularies at the end of a class that they must use in learning. Indirectly, online learning will reduce the target because no one will control the activity regularly.

Third, self-regulated learning (SRL) ability which is almost certainly still at a low 
level is becoming a particular challenge for students of Bahasa Indonesia. However, this ability must be had by University students to adapt to the various kind of learning, including distance learning (Carter, Rice, Yang \& Haidee, 2020). On the other side, this ability is to have self-control over the target of learning, evaluation, and ability measurement (Winne \& Hadwin, 2010). According to Teacher 3, students are still not able to set their targets, evaluate, and measure their abilities. This is also emphasized by the lack of enthusiasm in learning foreign languages of Thai students. Therefore, it is felt to be very ineffective when conducting online learning. It is because of their motivation to learn Bahasa Indonesia will also indirectly be reduced. Additionally, as students, some of them still live in an apartment or boarding house during this pandemic due. However, some are also returning home. However, parental involvement in online learning will not be effectively done. Therefore, if the student's self-regulated learning ability is categorized at a low level, this will be another challenge in learning Bahasa Indonesia.

Fourth, there is no control over the morals and behavior of students during learning. The ultimate goal of learning is a change in behavior in a better direction. According to Teacher 3 , the existence of moral and behavioral changes is not only intended for high school students, but it is very important for university students. Behavior towards foreign language learning will be different from other learning. In this pandemic era, it is very difficult to control it as no interaction that demands to control behavior during learning Bahasa Indonesia. However, they already have good behavior towards learning, but this kind of control must be done continuously.
Meanwhile, Student 1 and Student 2 stated that teaching and learning without direct interaction such as activity in the classroom are reducing the intention of learning very much. On the other hand, the emotional relationship between teachers and students has been being good since conventional learning conducted. It feels like being taught by friends. However, this pandemic chance it's an emotional relationship.

Overall, the problems experienced by the Bahasa Indonesia course were not related to technical problems, rather than the limitations of the communication language, the low ability of self-regulated learning, especially in learning Indonesian which is also a foreign language for them. The third is the problem of controlling student attitudes. However, student attitudes are one of the domains that must be assessed (Kemendikbud, 2017), because students must still get a fair assessment both inside and outside the classroom (James, 2015).

\section{2) Strategies Used during Online Learning}

Learning strategies are something that must be changed during online learning. It affects the solutions undertaken in the Bahasa Indonesia course. Shortly, this strategy is adjusted to the limited circumstances of space (distance learning). In learning Bahasa Indonesia during this covid-19 pandemics, the Thai government adopted an online learning policy to be implemented in University. Therefore, the role of technology is very important. However, due to several technologies improved these days, the instructors are expected to be selective in choosing technological platforms and strategies to be adopted in teaching and learning Bahasa Indonesia. It is hoped that the teaching 
matter will meet the target easily. It is about selecting the proper intermediary technologies to be used. There will be confusion in applying the technology in the learning and adaptation process once implemented together at the same time. The following are some strategies and technologies used during distance learning in Bahasa Indonesia.

First, the institution ensures students can access technology easily. However, with the high average use of supporting technology, its access is not becoming a problem for Thai students. However, it is not all can access technology easily. Therefore, the Thai government through educational institutions has collaborated with several providers to provide free internet access to regions that still do not have access before. This process is carried out to ensure that the long-distance or online learning policy adopted by the Thai government can run well. In learning Bahasa Indonesia, the teacher also ensures the same thing. Even before started, negotiation is done due to the learning platform that will be used. It is hoped that there is no one getting harmed in the Bahasa Indonesia learning process.

Secondly, the Thai government is also strengthening the involvement of parents in the process of children's learning from basic education to tertiary institutions as well as the university. It is a proposed way to control students' affective domain outside of the classroom (Qadafi, 2020; Borup, Chambers, \& Stimson, 2019). Teacher 1 said that parental involvement is intended as a substitute for the role of the teacher in instilling morals and attitudes. As university students, some of them can no longer be supervised by parents, therefore they are required to have self-regulated learning to determine, adapt, and evaluate their abilities. In learning Bahasa Indonesia, this becomes a challenge as the communication languages are not either Thai or Bahasa Indonesia. It is because of the limited abilities possessed by teachers in mastering Thai. On the other hand, students still have a limited ability to communicate using Indonesian daily. So English is the language of choice. As a result, limited parental involvement in the student educational process will become a weakness in the online learning system. So, no excuse for parents not to be involved in their children's education.

Third, in facilitating students' speaking skills, instructors are required to have unlimited creativity. Teacher 3 said that teachers' laboratory is a step taken to establish an emotional relationship among teachers and students. This is expected to be a media liaison between teachers and students by not increasing distance (Madjar, Kaplan \& Weinstock, 2011). For instance, videos related to learning are better produced by the instructor. Such as learning videos to stimulate students' speaking skills in Bahasa Indonesia is better made by the instructor. Furthermore, students can make a similar video as a form of speaking practice. In general, teachers can use videos sourced from other media such as YouTube, Facebook, and others. However, the emotional relationship that is intertwined will not be as good as if the video is directly made and rolled by the teacher. Therefore, the term teacher's laboratory is used to create contextual teaching material and intended to increase emotional relationships among students and teachers.

Fourth, self-assessment is a strategy used in learning Bahasa Indonesia during this pandemic era. This is a form of reciprocity or reflection of self-regulated learning ability owned by students. Besides, self-assessment is an effort of doing assessments in case that is not possible for teachers to do. Therefore, in situations of 
online learning, self-assessment is very crucial to do, said Teacher 2.

While Student 1 and Student 2 said that teachers' creativity will change all of the negative impacts of online learning previously predicted. The teacher should produce interactive activities during teaching and learning. To sum up, those four findings can be concluded that technology-based learning is something that cannot be avoided since the instruction of conducting online learning is exist. Therefore, in Bahasa Indonesia, negotiating and making an agreement related to the platform that will be used during long-distance or online learning is much more needed. In the other techniques, the teaching laboratory which is expected to make an emotional connection between teachers and students is well established as well as continued to have endeavored. On the other hand, as a form of reflection of self-regulated learning, students need to make an assessment of themselves or self-assessment.

\section{3) Solutions Offered in Bahasa Indonesia Course during Online Learning}

In a school scope of learning, the teacher is the curriculum maker in the smallest environment (Art-in, 2018). Therefore, the learning process should be flexible. As the ultimate goal is a change in student behavior for the better, the teacher must know what and how are the needs assessment expected of students. In learning Bahasa Indonesia, the teacher group has determined the needs of students who are aligned with a curriculum that has been previously designed. However, several proposed solutions are carried out during the online learning of Bahasa Indonesia.

First, the use of technological-based learning platforms that can not be avoided seems to be true. Therefore, inevitably technology through various platforms will be widely used. According to Teacher 1, technology-based learning is now a must. ICT Literacy is a skill that must be had by students in this industrial revolution 4.0 era. It is in line with the skills expected in the 21st Century Skill that students do have to master information and communication technology. In learning Bahasa Indonesia, the technology used is e-learning platforms, such as e-learning which was previously initiated by Khon Kaen University. Furthermore, other platforms such as google classroom, quiz, Edmundo, and several other social media such as Facebook, Line, and Youtube are also involved. Learning resources that are easy to find also provide practical solutions. However, still, students must have good self-regulated learning abilities in utilizing this distance learning.

Second, short pre-recording video production to support the learning process of Bahasa Indonesian belongs to other provided solutions. It is done to improve interactive online learning. In language learning, speaking skills become the priority of communication. Apart from that, the emotional connection process between lecturers and students must be well maintained. One way is to use a video conference platform (Carter, Rice Yang \& Haidee, 2020). As Teacher 2 said that through the short video which is containing the topic set by the teacher of Bahasa Indonesia, students are expected to be able to produce similar videos according to the instructions given by the instructor. On the other hand, it will increase students' motivation on learning Bahasa Indonesia. However, it is supposed to be a medium for improving the speaking skill of Bahasa Indonesia.

Third, instructors are required to simplify the level of difficulty of teaching. 
Teacher 3 said that during the learning process of Bahasa Indonesia, the level of difficulty of the material will affect students' interest in learning. However, interesting teaching technique by teachers is highly recommended. This is done to maximize student participation. However, student participation during distance learning is very much decreased. Therefore, to maximize student participation, teachers are expected to simplify the material but prefer to maximize meaningful learning.

Fourth, multi-literacy learning is expected to do during this pandemic. Teacher 2 stated that students must set themselves to learn from the sources coming from the nearest environment. This is still related to selfregulated learning skills students must have. On the other hand, teachers must adjust and not require them to learn using various sources that are unreachable. But instead, students have the right to learn from various sources both based on technology, and the nature around them. Multi-literacy learning is naturally coming from what they have.

Besides, Student 1 and Student 2 stated that technology assist will help teach and learn very much. However, when it is done by all lecturers, students will get dizzy easily. Task-dominated learning will automatically be done. However, technology is just a tool, it cannot change the emotional relationship between teachers and students.

In general, the perceived solutions taken in the Bahasa Indonesia course refer to solutions related to teaching methods and strategies. While the use of technology is something that cannot be avoided anymore. Additionally, the undertaken solutions are also adjusted to the difficulties and circumstances of foreign language learners as it is different from learning their first language. Lastly, self-regulated learning is much needed to face teaching and learning during distance learning.

\section{Conclusion}

As a foreign language, Bahasa Indonesia has its difficulties in the learning process for foreign students such as Thai students. Therefore, as the purpose of this study, Indonesian language teachers identified several problems that arose to furtherly formulate learning solutions and strategies. The problem concluded is in the form of semantic barriers, communication barriers between teachers and students when this pandemic becomes an additional problem. Besides learning by using a platform, not doing face to face directly, becomes a problem in learning a foreign language. Especially for students who still need guidance because their level of understanding is still low. The low ability of students' self-regulated learning towards learning Bahasa Indonesia is an additional challenge where they should be able to formulate learning, adapt needs, and evaluate independently. In this case, there needs to be an external role such as the involvement of parents in overseeing the learning process.

On the other hand, the solution offered during this distance learning is to keep using a technology-based platform that can support the process of distance learning by doing negotiation and prior agreement. Next is to make a short video as teaching material. This is expected to increase student motivation in learning Indonesian. Then, a simplification of the difficulty level of teaching materials will be carried out. This solution was taken to increase participation and reduce existing burdens while remaining guided by meaningful learning. The final thing is multiple literacy learning. The instructor does not require students to conduct learning through unreachable sources. Students have 
the right to determine learning resources following abilities and capacities that do not burden them and their families. For example, learning that is based on the environment.

In the meantime, several strategies adopted in strengthening the involvement of students in learning Bahasa Indonesia also prioritize the principle of compromise and negotiation. The first step taken is to ensure that students can access technology easily. Furthermore, parent involvement is expected to remain a priority, especially in monitoring and monitoring attitudes and values. This is a very important foundation in education. Next, is the student asked to do a selfassessment. This is expected to be a reflection of self-regulated learning which is predicted to be the main key for students during distance learning. The research conclusion is presented briefly, narrative, and conceptual which describes the research findings and their impacts.

\section{References}

Art-In, Sittiphon. (2018). Curriculum Development. Khon Kaen: Khon Kaen University Press

Bangkok Post. (2020). Emergences Degree Extended. Retrieved July, 27 $7^{\text {th }} 2020$, from

https://www.bangkokpost.com/thailand/ general/1955831/emergency- decreeextended

Borup, J., Chambers, C.B. and Stimson, R. (2019). Online Teacher and On-Site Facilitator Perceptions of Parental Engagement at A Supplemental Virtual High School. The International Review of Research in Open and Distributed Learning, 20(2), 79-95.

Brown, H. D. (2007). Teaching by Principles: An Interactive Approach to Language Pedagogy. (2 ${ }^{\text {nd }}$ ed.). New York: Longman.

Carter, R.A., Rice, Mary., Yang, Sohyun., Jackson Haidee A. (2020). SelfRegulated Learning in Online Learning
Environments: Strategies for Remote Learning. Information and Learning Science. Doi: 10.1108/ILS-04-20200114

Cohen, S., \& Hersh, R. (1972). Behaviorism and Humanism: A Synthesis for Teacher Education. Journal of Teacher Education, 23(2),172-176

Fatma, F., Prayitno, H. J., Jamaludin, N., Jha, G. K., \& Badri, T. I. (2019). Directive Speech Acts in Academic Discourse: Ethnography of Communication from Gender Perspective in Higher Education. Indonesian Journal on Learning and Advanced Education (IJOLAE), 2 (1), 27-46.

Greenstone, M., \& Nigam, V. (2020). Does Social Distancing Matter? Becker Friedman Institute for Economics Working Paper Series, (26). Doi: 10.2139/ssrn.3561244

Hanafi, H., Adu, L., \& Muzakkir. (2018). Profesionalisme Guru dalam Pengelolaan Kegiatan Pembelajaran di Sekolah (1st ed.). Yogyakarta: Deepublish.

Hidayat, Dasrun, \& Noeraida. (2020). Pengalaman Komunikasi Siswa Melakukan Kelas Online Selama Pandemi Covid-19. Jurnal Ilmu Komunikasi Efek, 3 (2). 172-182. Doi:10.32534/jike.v3i2.1017

James, Mary. (2015). Educational Assessment: Overview. United Kingdom: McGaw.

Kemendikbud. (2017). Panduan Penilaian oleh Pendidik dan Satuan Pendidikan. Jakarta: Kementerian Pendidikan dan Kebudayaan Direktorat Jenderal Pendidikan Dasar dan Menengah Direktorat Pembinaan Sekolah Menengah Pertama

Kompas. (2020). Thailand Menutup Semua Sekolah Selama 2 Minggu untuk Cegah Corona Retrieved July 24, 2020, from https://www.kompas.com/tren/read/2020 /03/17/211924065/thailandmenutup- 
semua-sekolah-selama-2-minggu-untukcegah corona?page $=$ all

Lenunberg, Fred C. (2010). Communication: The Process, Barriers, And ImprovingEffeciveness. Schooling, 1 (1), 1-11.

Madjar, N., Kaplan, A. and Weinstock, M. (2011). Clarifying mastery-avoidance goals in high school: distinguishing between intrapersonal and task-based standards of competence. Contemporary Educational Psychology, Vol. 36 No. 4, pp. 268-279.

Miles, Matthew B., Huberman, A Michael., Saldana, Jhonny. (2009). Qualitative Data Analysis: A Methods Sourcebook. USA: Arizona State University.

O’Malley, J.M. \& A.U. Chamot. (1990). Learning Strategies in Foreign language Acquisition. Cambridge: Cambridge University Press.

Prayitno, H. J., Kusmanto, H., Nasucha, Y., Rahmawati, L. E., Jamaluddin, N., Samsuddin, S., \& Ilma, A. A. (2019). The Politeness Comments on The Indonesian President Jokowi Instagram Official Account Viewed From Politico Pragmatics and The Character Education Orientation in The Disruption Era. Indonesian Journal on Learning and Advanced Education (IJOLAE), 1(2), 52-71.

Prihatsanti, Unika., Suryanto., Hendriani, Wiwin. (2018). Menggunakan Studi Kasus sebagai Metode Imliah dalam Psikologi. Buletin Psikologi, 26 (2), 126-136.

Doi:10.22146/buletinpsikologi.38895

Qadafi, Muammar. (2020). Pembelajaran Bahasa Inggris pada Anak di Sangkhom
Islam Wittaya School saat Pandemi Covid-19. Jurnal Pedikan Anak Usia Dini, 5 (1), 422-430.

Doi10.31004/obsesi.v5i1.591

Rice, M., Oritz, K., Curry, T. and Petropoulos, R. (2019). A Case Study of A Foster Parent Working to Support A Child with Multiple Disabilities in A Full-Time Virtual School. Journal of Online Learning Research, Vol. 5 No. 2, pp. $145-168$

Smith, R. D. (2005). Strategic Planning for Public Relations. New Jersey: Laurence Erlbaum Associates Publishers. UNESCO (2020), COVID-19 impact on education. Retrieved July $20^{\text {th }}, 2020$ from:

https://en.unesco.org/covid19/educationr esponse

WHO. (2020). Pertanyaan dan Jawaban Terkait Corona Virus. Retrieved July $23^{\text {rd }}$, 2020, from https://www.who.int/indonesia/news/no vel-coronavirus/qa-for-public

Winne, P.H. and Hadwin, A.F. (2010). SelfRegulated Learning and Socio-Cognitive Theory, in McGaw, B., Baker, E., Peterson, P. (Eds), 3rd ed. New York: International encyclopedia of education

Yunardi. Sistem Pendidikan di Thailand, Kantor Atase Pendidikan, Kedutaan Besar Republik Indonesi, Bangkok, 2014Baddeley, A. (2012). Working memory: theories, models, and controversies. Annual Review of Psychology, 63, 1-29. http://doi.org/10.1146/annurevpsych120710-100422. 